\title{
Conceptual metaphor in the public service advertising (PSA) discourse on migration crisis and poverty in Great Britain and Germany
}

\author{
T. V. Tsyliuryk
}

Taras Shevchenko National University of Kyiv, Kyiv, Ukraine

Corresponding author. E-mail: tsyliuryk.t@gmail.com

Paper received 06.11.9; Accepted for publication 21.11.19.

\begin{abstract}
https://doi.org/10.31174/SEND-Ph2019-212VII63-17
\end{abstract}
Abstract. The article reviews the metaphorical representation of migration crisis and poverty in the British and German public service advertising (PSA), compares it with the representation of the two social phenomena in mass media discourse of both countries and defines the pragmatic potential of the used metaphorical models. In both types of discourse, victimization of migrants, refugees, asylum seekers and people in need takes place. Contrary to mass media discourse, in PSA the metaphorical concept of THREAT/DANGER and dehumanization frame are absent, which is due to the values of humanitarian organizations.

Keywords: metaphorical representation, migration crisis, poverty, public service advertising (PSA), victimization, dehumanization.

Introduction. Migration crisis and poverty are one of the burning social phenomena in the world. Therefore, they take the leading positions among other themes in the discourse of public service advertising (PSA) in Great Britain and Germany. Migration crisis has a controversial nature. On the one hand, it broadens the opportunities for socio-economic development, facilitates cultural exchange, encourages labour force growth of the receiving country. On the other, migration crisis is often a cause of destabilization of the receiving society [4;6].

Brief review of publications on the topic. A large body of studies has lately analyzed the metaphorical expressions that have shaped the British and German discourse on immigration, as reflected by mass media and political discourse (Böke, 1997 [10]; El Refaie, 2001 [13]; Kalygina, 2009 [4]; KhosraviNik, 2009 [15]; Chochlova, 2014 [7]; Musolff, 2015 [17]; Greussing \& Boomgaarden, 2017 [14]; Khismatullina, 2017 [6]; Müller, 2017 [18] among others). The metaphorical representation of migration crisis and poverty in the discourse of PSA, however, has not been investigated.

The research on metaphor is one of the directions of modern cognitive linguistics, which rejects the traditional (from the times of Aristotle [9]) definition of this stylistic device as "a condensed simile" or as one of the means of "speech elaboration". Cognitive linguistics also rejects the definition of metaphor as an interrelation of two basic structures (deep structure and surface structure), peculiar for generativism (N. Chomsky) [11]. Structuralist views on metaphor (F. de Saussure and his followers), which emphasize exclusively linguistic aspects of metaphorization, are not supported by cognitive linguists, either [8, p. 7-8]. Modern cognitive science (developed by G. Lakoff \& M. Johnson [16]) defines metaphor as a way of thinking, conceptualization and categorization of the world, which creates the whole language picture of the world $[16 ; 4 ; 6 ; 8 ; 19]$.

Cognitive linguistics views conceptual metaphor as the process of understanding of one concept, or domain, in terms of the other. Within it, metaphor is formed as a result of mapping from a source domain to a target domain $[16$, p. $5 ; 19$, p. 194]. During metaphorization, specific characteristics of the main object are chosen, emphasized and organized, while other characteristics are avoided, which leads to meaning shifts [16, p. 163]. This way, metaphors allow us to emphasize peculiar characteristics of the object as well as give the object new characteristics not typical for it. In terms of the PSA texts, it is important that these metaphorical associations are quickly activated in the mind of the producer and recipient [5, p. 127-135].

In communication, metaphor is an important means of influence on the intellect and emotions of the addressee. The basis of metaphor is a human being, their experience, social environment and activities [1, p. 55]. In advertising, on the one hand, it is a producer of advertising, who encodes the ideas in metaphors and creates a metaphorized image of reality. On the other hand, it is a recipient, who reconsiders these metaphors and creates their own picture of the world.

In PSA, metaphor is used for emotional influence on the recipient, influence on his associative thinking - therefore, as a means of manipulation [3]. The goal of metaphorical models in PSA is to attract the attention and trigger emotional memory of the addressee by provoking certain emotions. These emotional effects considerably increase suggestiveness of PSA texts: target audience becomes deeply involved in the situation described.

The study of the semantics of metaphors reveals socio-economic and political history of the country; and the use of certain metaphorical models gives us an insight into the current situation of the country, its social problems [2, p. 71]. Metaphors as a mirror of national cultural consciousness can concisely convey generally accepted conceptions about certain phenomena, turn ideas into a representation system [6].

According to Mark Ellis and Richard Wright, metaphors are "more than descriptive instruments that can enhance our understanding of immigration and ethnic groups. They represent competing views, some more distinct than others, of the consequences of immigration, interethnic contact, and societal coherence. In using metaphors ... we run the risk of being confined to particular ways of interpreting immigration and demographic trends. As they become entrenched in theoretical discourse, they influence how we formulate our hypotheses about the impact of immigration and ethnic group behavior-about how different immigrant groups fit into ... society" [12, p. 688].

The aim of the research is to review the most productive conceptual metaphors representing migration crisis and poverty in the PSA discourse in Great Britain and Germany, define their pragmatic potential and compare them with the representation of the two social phenomena in mass media discourse of both countries.

Data and methods. This study builds on a dataset of 75 examples of print and static online PSA in Great Britain and Germany, representing migration crisis and poverty. The dataset includes PSA campaigns of the following British organizations: Care International UK, Amnesty International UK, Save the Children UK, Practical Action, UNICEF UK, People`s Needs. Among German PSA, the campaigns of the following organizations were analyzed: Brot für die Welt, World Vision Deutschland, Diakonie Katastrophenhilfe, 
Kindernothilfe, Ärzte ohne Grenzen, beBerlin, Caritas Deutschland, SONNE-International.

Comparative analysis of metaphors, in combination with the methods of cognitive-discursive and linguo-cultural approach, allowed us to study the conceptualization of migration crisis and poverty in the PSA discourse of Great Britain and Germany. All the identified metaphors were grouped according to the conceptual metaphor theory and classifications by G. Lakoff \& M. Johnson [16] and A. Chudinov [8].

Results and their discussion. In the British and German press, migrants, refugees and asylum seekers are portrayed as innocent victims and, simultaneously, as invaders and threat to the economic and cultural well-being of the respective host country $[14 ; 6 ; 13 ; 4 ; 10 ; 7]$. The most productive metaphors in the representation of migration crisis in the British and German journalistic discourse are: hydronimic metaphors (DANGEROUS WATERS metaphors) with the negative connotation, which depict migrants as an uncontrollable powerful force with disastrous consequences for the recipient communities (immigrants are flooding, huge wave of migrant workers, an influx of immigrants; der Strom der Migranten, der Zustrom, der Flüchtlingsstrom, die Welle, der menschliche Tsunami); SPORTS/GAME metaphors with the negative pragmatic potential, as a game is perceived as an imitation of reality and immigrants are represented as OPPONENTS (immigrants can`t win, hunting illegal immigrants); economic metaphors, which view migrants as GOODS (to import millions of foreigners, immigration is already a net moneyspinner for Britain, immigrant communities are a "debit" and some are a "credit" on "Britain's balance sheet"); morbial metaphors, which identify migration as ILLNESS (lunatic immigration policy, the immigration system in this country is truly mad, neurosis about immigration); military metaphors, within which migration crisis is seen as A THREAT for the receiving country, and a migrant is seen as AN ENEMY (MPs are now also turning their firepower on immigration; massiver, dramatischer, stark anschwellender Ansturm, Flüchtlingsansturm, die Invasion, das Land in die Knie zwingen) [4; $6 ; 10 ; 7 ; 18]$. Thus, in the representation of migration crisis in the British and German press the most frequent metaphorical concept is of THREAT/DANGER. It is also apparent that metaphors in the British and German press dehumanize immigrants and refugees $[14 ; 17]$. Germany and Great Britain are portrayed as closed CONTAINERS with no place for the "others" [17, p. 45].

In PSA migration crisis and the population of third-world countries, countries affected by war or natural disasters are represented differently. This is due to the values of humanitarian organizations: humanity, impartiality and neutrality. In the following, we will analyze the metaphorical models used to describe the phenomena of migration crisis and poverty in the British and German PSA:

- $\quad$ Military metaphors (source domain FIGHT):

«Fighting poverty. Defending dignity» [CARE International UK] - target domains POVERTY and DIGNITY. In this example, solving poverty is described as a fight; poverty is opposed to dignity; dignity is a value.

"Hunger ist keine Naturkatastrophe. Wir können ihn bekämpfen. Helfen Sie uns, den Kampf zu gewinnen!'» [Brot für die Welt] - target domain HUNGER.

«Help keep refugee families together. When we all act, humanity wins» [Amnesty International UK] - target domain HUMANITY; family as a value.

«EMERGENCIES. When disaster strikes, children need your support to survive» [Save the Children UK] - target domain NATURAL DISASTERS; child`s life as a value.

"Giving people a voice. We tackle the unequal power relations that cause and perpetuate poverty. Learn more/Donate» [CARE International UK] - target domain INEQUALITY; social inequality is considered to be a reason of poverty; equality as a value.

«Zusammen mit 170.000 Unterstützern kämpfen wir gegen Armut» [World Vision Deutschland] - target domain POVERTY.

«Das schönste Geschenk für Kinder: eine Zukunft. Das ist die Kraft der Patenschaft» [World Vision Deutschland] - target domain ADOPTION OF CHILDREN FROM UNDERDEVELOPED COUNTRIES; child`s future as a value.

- Orientational metaphors (source domain MOVEMENT):

«LENDWITHCARE. You can help some of the world's poorest people to work their way out of poverty. Learn more» [CARE International UK] - target domain POVERTY.

«Empowering women and girls. Fighting poverty. When one woman is helped out of poverty, she brings many other people with her. Learn more/ Donate now» [CARE International UK] - target domain POVERTY.

«Empowering women and girls. Every woman who lifts herself out of poverty takes her family and her community with her. Learn more/ Donate now» [CARE International UK] target domain POVERTY; family as a value.

"Jemen. Nothilfe gegen Hunger und Krankheiten. Es ist die größte humanitäre Katastrophe der Welt: Der seit März 2015 andauernde Konflikt im Jemen hat das Land in unermessliche Not gestürzt...» [Diakonie Katastrophenhilfe] - target domain POVERTY; health as a value.

The analysis of the examples above has shown that in the British and German PSA poverty is portrayed as THE BOTTOM where people fall and hope to get out of -orientational opposition TOP-BOTTOM. In English it is represented by the construction: «verb + (noun/pronoun $)+$ out of poverty». As for the representation of third-world countries and their population, victimization takes place: the attention of the recipient is drawn to the plight of the people in need, they are seen as innocent victims of circumstances seeking help [14; 15].

In the German PSA in support of the children from wartorn and economically disadvantaged countries, the situation is described as HELL, from where the children hope to get out and find at least a piece of HEAVEN: «Das Leben in der Stadt ist kein Kinderspiel. In Städten hoffen Kinder auf ein Stück

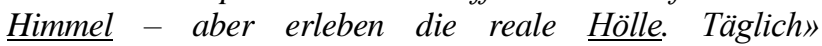
[Kindernothilfe] - orientational opposition HELLHEAVEN.

In the British advertising, malnourished children are viewed as ON THE BRINK. With financial help from the addressee, humanitarian organizations hope to bring these malnourished children back to a healthy condition: «£5 could buy enough nutrient-rich food to bring a child like Imani back from the brink» [Save the Children UK] - orientational opposition CENTRE-ON THE BRINK.

- Physiological metaphors (source domain SYSTEMS \& PARTS OF THE BODY):

"Giving people a voice. We tackle the unequal power relations that cause and perpetuate poverty. Learn more/Donate» [CARE International UK] - target domain FREEDOM OF SPEECH.

"A child 's life is in your hands» [Save the Children UK] target domain RESPONSIBILTY; child`s life as a value. 
«Bildung ändert alles. Kindernothilfe. Gemeinsam verändern wir die Welt: Wie mit Ihrer Hilfe Kinder weltweit lernen, ihr Leben selbst in die Hand zu nehmen, erfahren Sie unter www.kindernothilfe.de» [Kindernothilfe] - target domain RESPONSIBILITY; education as a value.

As can be seen from the examples above, while the British advertising depicts a child in need as an innocent victim of circumstances and its life as dependent on a recipient's donation, the German advertising places the responsibility of the children for their future lives on them: a recipient's donation is just a means to help them receive decent education.

- Source domain THREAT - target domain NATURAL DISASTERS:

«Will you help keep refugee families safe? Monsoon rains, floods and landslides are threating the lives of Rohingya refugee families like Anwara's. Find out more/ Donate now» [CARE International UK] - safety and lives of refugees as values.

«ÄRZTE OHNE GRENZEN HILFT. MIT IHRER HILFE... ÄRZTE OHNE GRENZEN hilft dort, wo das Leben vieler Menschen durch Gewalt oder Naturkatastrophen bedroht ist» [Ärzte ohne Grenzen] - life and safety as values.

"Resilience that protects. For vulnerable people whose lives and livelihoods are threatened by climate related and natural hazards» [Practical Action] - life and safety as values.

- Phytomorphic metaphors (source domain PLANTS \& PARTS OF PLANTS):

"How we fight poverty. We work with women, girls and poor communities around the world to cut out poverty at its roots. Learn more/ Donate now» [CARE International UK] target domain POVERTY; the metaphor of ROOTS is used to signify the reason of poverty.

«Ich bin Deutsche weil doppelte Wurzeln besser halten», Chung Noh. Deine Stadt. Dein Land. Dein Pass» [Einbürgerung, beBerlin] - target domain NATIONALITY/IDENTITY; integration of migrants into the recipient community as a value.

Only in the British PSA the following metaphorical models were identified:

- Source domain BUILDING - target domain POVERTY:

«Your donation options. Whatever you give, however you choose to give it, your donations help us connect thousands of communities to the ingenious solutions they need to build a life free from poverty. Thank you» [Practical Action] - the metaphor of BUILDING signifies CREATION of life free from poverty.

\section{- Source domain KEY:}

«FOOD FOR THOUGHT. 200 million children suffer from malnutrition. Could empowering women be the key to giving children a better life? Learn more/ Donate» [CARE International UK] - target domain SOLUTION; health and life of children as values.

«Empowering women and girls. UNLOCKING POTENTIAL. Women put in two-thirds of the world's working hours, yet make only $10 \%$ of the world's income. We aim to change that. Learn more/ Donate now" [CARE International UK] target domain NEW OPPORTUNITIES; pay equality as a value.

- Source domain FOOD:

«FOOD FOR THOUGHT. 200 million children suffer from malnutrition. Could empowering women be the key to giving children a better life? Learn more/ Donate» [CARE International UK] - target domain IDEAS TO CONSIDER.
«Donate now and help feed a child's future» [UNICEF UK] - target domain CHILD`S FUTURE.

- Source domain BRIDGE - target domain HUMANITARIAN ORGANIZATION, which connects a recipient of advertising with the people in need: "People's needs. A bridge between you and the needy» [People's Needs].

Only in the German PSA the following metaphorical models were found:

- $\quad$ Source domain CHILD'S GAME - target domain CHILD'S LIFE IN THE COUNTRIES AFFECTED BY CONFLICT OR DISASTER:

"Himmel und Hölle. Das Leben in der Stadt ist kein Kinderspiel!!» [Kindernothilfe] - this example emphasizes the hardships children face in the countries affected by conflict or disaster. A child's game is supposed to be light and funny, which is opposed to the real life of the children. They have no childhood.

- Source domain DISASTER:

"Die grösste Katastrophe ist das Vergessen. Hunger in Ostafrika. Dürre, Krieg und Flucht. Ihre Spende hilft!» [Caritas Deutschland] - target domain FORGETTING.

"Die größte Katastrophe ist, nichts zu tun. Werden Sie Caritas Helferin/Helfer auf www.caritas.at» [Caritas Deutschland] - target domain INACTION.

Forgetting about the problem and inaction are hyperbolized to the biggest disasters.

- $\quad$ Source domain GIFT - target domain ADOPTION OF CHILDREN FROM UNDERDEVELOPED COUNTRIES:

"Ihre Kinderpatenschaft... schenkt mir Hoffnung» [SONNE-International] - target domain HOPE.

«Für tausende Kinder Osteuropa ist das Leben kein Spiel. Caritas \& Du schenken ein Zuhause» [Caritas Deutschland]target domain HOME.

«Das schönste Geschenk für Kinder: eine Zukunft. Das ist die Kraft der Patenschaft» [World Vision Deutschland] - target domain FUTURE.

«Schenken Sie einem Kind seinen ersten Geburtstag» [World Vision Deutschland] - target domain FIRST BIRTHDAY.

Conclusions. The results of our research have shown that, contrary to the representation of migrants, refugees and asylum seekers in the British and German press (where they are portrayed as innocent victims and, simultaneously, as invaders and threat to the economic well-being and cultural identity of the host country), in the PSA discourse the metaphorical concept of THREAT/DANGER is absent. Dehumanization frame is also absent, as immigrants, refugees and people in need are portrayed as human beings having the same values and needs as the recipients of advertising. This is due to the values of humanitarian organizations: humanity, impartiality, neutrality. In PSA migrants, refugees and asylum seekers, as well as the population of the countries affected by conflict and disaster are represented as innocent victims of circumstances (victimization); and German and British humanitarian organizations unite with them in the fight against poverty, hunger and social inequality; help them overcome the consequences of natural disasters. German NGOs find foster parents for the children from underdeveloped countries, promote dual citizenship for migrants and help them integrate into the receiving society.

The choice of the metaphorical models used to represent migration crisis and poverty in the PSA discourse in Great 
Britain and Germany is determined by the negative consequences of these phenomena for certain individuals and society as a whole. Dealing with migration crisis and poverty is often described as A FIGHT (military metaphors) (fighting poverty, defending dignity, Hunger bekämpfen, den Kampf gewinnen, humanity wins, disaster strikes, tackle the unequal power relations, gegen Armut kämpfen, die Kraft der Patenschaft) and as A BOTTOM-UP MOVEMENT, where BOTTOM IS POVERTY (orientational metaphors) (to work somebody`s way out of poverty, to be helped out of poverty, to lift oneself out of poverty, das Land in Not stürzen). Poverty is also represented in the orientational oppositions HELLHEAVEN (Himmel und Hölle) and THE BRINK-CENTRE (to bring the child back from the brink), where POVERTY IS HELL, BEING ON THE BRINK. Humanitarian organizations fight for the freedom of speech in underdeveloped countries (give people a voice) and take responsibility for children`s lives ( $a$ child`s life is in your hands, das Leben selbst in die Hand nehmen) - physiological metaphors. NATURAL DISASTERS ARE A THREAT to the lives of people (are threating the lives, das Leben ist bedroht, resilience that protects). NGOs strive to identify the causes of poverty and eliminate them (to cut poverty at its roots) and promote dual nationality for migrants (doppelte Wurzeln besser halten) phytomorphic metaphors.

In the British PSA, creation of life free from poverty is metaphorized as BUILDING (to build a life free from poverty), solution to a better life as A KEY (the key to giving children a better life) and finding new opportunities as UNLOCKING POTENTIAL. Humanitarian organization is viewed as A BRIDGE between the target audience of advertising and the people in need (a bridge between you and the needy). Source domain FOOD is used to signify IDEAS TO CONSIDER (food for thought) and A BETTER AND HEATHIER FUTURE OF THE CHILDREN (feed a child's future).

In the German PSA, inaction and forgetting about the problem is metaphorized as THE BIGGEST DISASTER (die grösste Katastrophe ist das Vergessen, die grösste Katastrophe ist, nichts zu tun); source domain CHILD'S GAME is used to signify all the hardships children face in the countries affected by conflict and war (das Leben in der Stadt ist kein Kinderspiel); and HOPE, HOME, FIRST BIRTHDAY, FUTURE are metaphorized as GIFTS in the advertising of child adoption (Hoffnung/ ein Zuhausel ersten Geburtstag schenken, das schönste Geschenk für Kinder: eine Zukunft).

\section{ЛИТЕРАТУРА}

1. Веснина, Л.Е. Метафорическое моделирование миграции (по материалам российских печатных СМИ и данным ассоциативного эксперимента): дис. ... канд. филол. наук/ Л.Е. Веснина. - Екатеринбург, 2010. - 250 с.

2. Виноградов, С.И. Выразительные средства в парламентской речи/ С.И. Виноградов// Культура парламентской речи. - М.: Наука, 1994. - С. 66-77.

3. Воронова, Н.С. Политическая метафора в немецком и русском языках: дис. ... канд. филол. наук/Н.С. Воронова. - М., 2003. $-181 \mathrm{c}$.

4. Калыгина, М.Ю. Метафорическая репрезентация миграции в медиадискурсе России, Великобритании и США/ М.Ю. Калыгина// Политическая лингвистика.-2009.-№29.-С. 109-113.

5. Тармаева, В.И. Метафорические именные словосочетания/ В.И. Тармаева// Проблемы и перспективы языкового образования в XXI веке: сб. материалов регион. науч.-практ. конф./ под ред. И.Д. Лаптевой. - Новокузнецк, 2004. С. 127-135.

6. Хисматуллина Л.Г. Метафорическая репрезентация миграции в британских, американских и русских СМИ/ Л.Г. Хисматуллина, А.К. Гараева, И.Г. Ахметзянов// Вестник ЧГПУ. 2017. - №2. - С.170-176.

7. Хохлова И.В. Метафоры в миграционном дискурсе Германии (на примере сообщений о беженцах в период «Арабской весны»)// Вестник КГУ. 2014. №1. - С. 185-188.

8. Чудинов А.П. Россия в метафорическом зеркале: когнитивное исследование политической метафоры (1991-2000): монография/ А.П. Чудинов. - Екатеринбург, 2001. - 238 с.

9. Aristoteles. (1982). Poetik, hg. u. übers. v. Manfred Fuhrmann, Stuttgart, S. 157.

10. Böke, K. (1997). Die "Invasion" aus den "Armenhäusern

Europas". Metaphern im Einwanderungsdiskurs. Die Sprache des Migrationdiskurses, S. 164-193.

11. Chomsky, N. (1972). Deep Structure, Surface Structure, and Semantic Interpretation. Studies on Semantics and Generative Grammar, pp. 62-119.

12. Ellis, M., \& Wright, R. (1998). The Balkanization Metaphor in the Analysis of U.S. Immigration. Annals of the Association of American Geographers, 88(4), pp. 686-698.

13. El Refaie E. (2001). Metaphors we discriminate by: Naturalized themes in Austrian newspaper articles about asylum seekers. Journal of Sociolinguistics, 5(3), pp. 352-371.

14. Greussing, E. \& Boomgaarden H. G. (2017) Shifting the refugee narrative? An automated frame analysis of Europe`s 2015 refugee crisis. Journal of Ethnic and Migration Studies, 43:11, pp. 17491774 .

15. KhosraviNik, M. (2009). The representation of refugees, asylum seekers and immigrants in British newspapers during the Balkan conflict (1999) and the British general election (2005). Discourse \& Society, 20(4), pp. 477-498.

16. Lakoff, G. \& Johnson, M. (1980/2003). Metaphors we live by. Chicago: University of Chicago Press.

17. Musolff, A. (2015). Dehumanizing metaphors in UK immigrant debates in press and online media. Journal of Language Aggression and Conflict, 3(1), pp. 41-56.

18. Müller, T. (2017). Constructing cultural borders: Depictions of Muslim refugees in British and German media. Zeitschrift für Vergleichende Politikwussenschaft, 2018(1), pp. 1-15.

19. Stöckl, H. (2010). Metaphor Revisited: Cognitive-conceptual versus Traditional Linguistic Perspectives. AAA: Arbeiten Aus Anglistik Und Amerikanistik, 35(2), S. 189-208.

\section{REFERENCES}

1. Vesnina, L.E. Metaphorical Modelling of Migration (based on the Russian printed media and association experiment data). Dis. ... cand. of Sciences (Philology). Ekaterinburg, 2010.pp. 250. [in Rus.].

2. Vinogradov, S.I. Expressive means in parliamentary speech. Culture of parliamentary speech. M.: Nauka, 1999. pp.66-77. [in Rus.].

3. Voronova, N.S. Political metaphor in the German and Russian languages. Dis. ... cand. of Sciences (Philology). Moscow, 2003. pp.181. [in Russian].

4. Kalygina, M.Yu. Metaphorical representation of migration in mass media discourse of Russia, Great Britain and the USA. Political linguistics, 2009. №29. pp.109-113. [in Russian].

5. Tarmaeva, V.I. Metaphorical noun combinations. Problems and perspectives of linguistic education in the XXI century: Scientific
Conference Materials. Novokuznetsk, 2004.pp.124-135. [in Rus.]. 6. Khismatullina, L.G., Garaeva, A.K., \& Akhmetzyanov, I.G. Metaphoric representation of migration in the British, American and Russian mass media. Bulletin of the Chelyabinsk State Pedagogical University, 2017. №2. pp.170-176. [in Russian].

7. Khokhlova, I.V. Metaphors in the migration discourse of Germany (demonstrated on press reports about refugees at the time of "Arab srping"). Bulletin of the N.A. Nekrasov State University of Kostromsk, 2014. №1. pp. 185-188. [in Rus.].

8. Chudinov, A.P. Russia in the metaphorical representation: Cognitive studies of political metaphor (1991-2000). Ekaterinburg, 2001. pp.238. [in Rus.] 